Sari, V.I. · A.B. Tambunan · S. Madusari

\title{
Respons pertumbuhan bibit kelapa sawit terhadap bioherbisida saliara di pembibitan awal
}

Sari Keberadaan gulma pada pembibitan kelapa sawit dapat menurunkan kualitas bibit. Pengendalian gulma di pembibitan awal harus dilakukan secara dengan tangan (hand weeding), karena bibit dapat mati akibat aplikasi herbisida. Aplikasi bioherbisida saliara (Lantana camara) pada bibit kelapa sawit (Elaeis guineensis Jacq.) dapat menjadi alternatif pengendalian gulma yang ramah lingkungan dan mengurangi tenaga kerja. Penelitian ini dilaksanakan di Kebun Percobaan 1 Politeknik CWE, pada November 2019 sampai Februari 2020. Percobaan disusun dalam Rancangan Acak Kelompok, dengan perlakuan: kontrol (tanpa aplikasi bioherbisida), Ekstrak Lantana camara 1\%, 2\%, dan 3\%. Setiap perlakuan diulangi sebanyak tiga kali. Hasil penelitian menunjukkan bahwa Bioherbisida Lantana camara mengandung senyawa alelokimia yaitu Saponin $(2,07 \%)$, Tanin $(3,28 \%)$, dan Flavonoid $(1,83 \%)$. Gulma Lantana camara dapat dijadikan bahan alternatif bioherbisida pra tumbuh karena berpengaruh nyata terhadap daya tumbuh gulma. Meskipun bioherbisida menurunkan tinggi bibit pada 3 bulan setelah tanam (BST) dan diameter batang bibit pada 1 BST, namun bioherbisida tidak mempengaruhi jumlah daun, kehijauan daun, dan biomassa bibit. Bioherbisida Lantana camara dengan konsentrasi 1\% menunjukkan hasil terbaik dalam menekan laju pertumbuhan gulma.

Kata Kunci: Bibit · Bioherbisida · Fisiologi · Gulma · Morfologi

\section{The growth responses of oil palm seedling to Lantana camara bioherbicide in prenursery}

\begin{abstract}
The presence of weeds in oil palm nurseries can reduce the quality of the seedlings. Usually, mechanical weeding by hand is needed in pre-nursery because the use of chemical treatment caused the oil palm seeeling died. Bioherbicide application of Lantana camara to oil palm seedling (Elaeis guineensis Jacq.) can be alternative weed control that is environmental friendly and reduces labor. This research conducted at Teaching Farm Politeknik CWE, from November 2019 to Februari 2020. Experiment was arranged in Randomized Block Design, with treatments are Control (without bioherbicide application), Bioherbicide Lantana camara 1\%, $\%$ and 3\%. Every treatments was repeated three times. The results showed that Lantana camara bioherbicide contained allelochemical compounds, namely saponins $(2.07 \%)$, tannins $(3.28 \%)$, and flavonoids $(1.83 \%)$. Lantana camara weed can be used as an alternative material for pre-growing herbicides because it has a significant effect on reduced weed population. Although bioherbicides decreased seedling height at 3 months after planting (MAP) and stem diameter at $1 \mathrm{MAP}$, bioherbicides did not affect leaf number, leaf greenness, and seedling biomass. Bioherbicide Lantana camara with concentration 1\% showed the best treatment for controlling weeds in oil palm pre nursery.
\end{abstract}

Keywords: Bioherbicide $\cdot$ Morphology $\cdot$ Physiology $\cdot$ Seedlings $\cdot$ Weed

Diterima : 3 Maret 2021, Disetujui : 17 Juni 2021, Dipublikasikan : 1 Agustus 2021 DOI: https://doi.org/10.24198/kultivasi.v20i2.32512

Sari, V.I. · A.B. Tambunan · S. Madusari

Politeknik Kelapa Sawit Citra Widya Edukasi

Korespondensi: vierairma@cwe.ac.id 


\section{Pendahuluan}

Gulma di pembibitan kelapa sawit (Elaeis guineensis Jacq.) menjadi salah satu masalah yang dihadapi untuk mendapatkan bibit yang baik. Hal ini disebabkan gulma berkompetisi dengan bibit dalam persaingan ruang tumbuh, cahaya matahari, dan karbondioksida (Antika et al., 2014). Keberadaan gulma di pembibitan secara tidak langsung dapat menurunkan produksi Tandan Buah Segar (TBS) sampai 20\% karena sifat kompetisi dan zat alelokimia yang dikandungnya. Oleh karena itu, gulma perlu dikendalikan agar tidak mengganggu pertumbuhan bibit (Rambe et al., 2010).

Pengendalian gulma di pembibitan awal kelapa sawit umumnya dilakukan secara hand weeding (mencabut gulma dengan tangan). Hal ini menyebabkan perlunya tenaga kerja yang banyak, karena jumlah polybag yang harus dibersihkan per ha sangat banyak. Jumlah bibit di areal pembibitan seluas 0,5 ha adalah sekitar 213,714 bibit, tenaga kerja yang dibutuhkan untuk mengendalikan gulma adalah sekitar 60 sampai 70 orang. Pertumbuhan gulma yang dapat dikendalikan sedini mungkin akan mengurangi kegiatan pengendalian gulma, sehingga juga dapat mengurangi tenaga kerja.

Bibit kelapa sawit yang masih terlalu muda belum tahan terhadap penyemprotan herbisida sintetik, sehingga perlu bahan alternatif untuk mengendalikan gulma, seperti herbisida nabati atau bioherbisida. Bioherbisida adalah produk pengendalian gulma yang berasal dari organisme hidup yang mampu menekan pertumbuhan gulma dan mengurangi risiko pencemaran lingkungan. Bioherbisida dapat mengurangi resistensi dan toksisitas herbisida (Bailey, 2014).

Bahan organik yang dapat digunakan untuk pembuatan bioherbisida adalah gulma. Limbah dari pengendalian gulma sangat banyak sehingga berpotensi untuk dimanfaatkan. Gulma juga mengandung senyawa alelokimia, salah satunya adalah saliara (Lantana camara). Gulma ini mengandung senyawa alkaloid (lantanine), flavonoid, dan triterpenoid (Asrani, 2010). Bioherbisida Lantana camara dengan konsentrasi 30\% diketahui mampu menghambat perkecambahan dan anakan Acacia (Mirnawati et al., 2017). Sari (2018) juga melaporkan bahwa ekstrak bioherbisida Lantana camara mampu menurunkan jumlah gulma sebesar 36\% dibandingkan perlakuan tanpa pemberian ekstrak.

Bioherbisida Lantana camara yang diperoleh selama pengendalian gulma diharapkan mengandung senyawa alelokimia yang dapat mengendalikan gulma di masa pembibitan awal sehingga mampu mengurangi tenaga kerja untuk melakukan hand weeding. Kualitas bibit juga diharapkan dapat ditingkatkan dengan penekanan pertumbuhan gulma melalui aplikasi bioherbisida Lantana camara. Oleh karena itu, penelitian ini perlu dilaksanakan untuk mengetahui efektivitas bioherbisida terhadap pengendalian gulma dan kualitas bibit.

\section{Bahan dan Metode}

Penelitian ini dilaksanakan di Kebun Percobaan I Politeknik Kelapa Sawit Citra Widya Edukasi selama bulan November 2019 sampai Februari 2020. Analisis kandungan ekstrak dilakukan di Balai Penelitian Tanaman Rempah Dan Obat (BALITRO), Jalan Tentara Pelajar No. 3, Cimanggung, Bogor Tengah, Kota Bogor, Jawa Barat. Alat-alat yang digunakan adalah gelas ukur, pisau, timbangan, lesung, ember, gelas plastik, saringan, ATK, penggaris atau meteran, timbangan digital analitik, gembor, oven, Chlorophyllmeter SPAD 502, label plot dan sampel, kamera, serta alat tulis. Bahan-bahan yang digunakan terdiri atas daun Lantana camara, kompos kotoran sapi, tanah sub-soil, air, kecambah sawit varietas Sue Supreme Mekarsari, dan fungisida bahan aktif Mankozeb (Sidazeb).

Penelitian ini disusun dalam Rancangan Acak Kelompok (RAK) dengan empat perlakuan, yaitu kontrol (tanpa pemberian bioherbisida), ekstrak Lantana camara 1\%, ekstrak Lantana camara 2\%, dan ekstrak Lantana camara $3 \%$. Setiap perlakuan diulang sebanyak tiga kali sehingga total unit percobaan adalah dua belas unit. Setiap unit percobaan terdiri atas tiga sampel, sehingga jumlah tanaman seluruhnya adalah 36 tanaman. Pengolahan data dilakukan menggunakan Analysis of Variance (ANOVA) pada taraf nyata $5 \%$. Apabila data berpengaruh nyata, maka dilanjutkan dengan Uji Lanjut Duncan Multiple Range Test (DMRT).

Pembuatan ekstrak dilakukan dengan cara menghaluskan daun gulma sebanyak $1 \mathrm{~kg}$, 
kemudian dicampurkan dengan air sebanyak 1 liter. Campuran daun gulma dan air tersebut direndam selama 24 jam dalam kondisi hampa udara. Larutan yang sudah direndam kemudian disaring, sehingga diperoleh larutan stok bioherbisida. Aplikasi bioherbisida pada bibit dilakukan dua kali yaitu saat bibit berumur satu dan dua bulan. Pembuatan konsentrasi 1\% dilakukan dengan cara mencampurkan larutan stok sebanyak $1 \%$ (10 mL larutan stok ke dalam $990 \mathrm{~mL}$ air). Analogi yang sama dilakukan untuk perlakuan 2\% dan 3\%. Parameter pengamatan yang dilakukan yaitu analisis kandungan alelokimia Lantana camara, daya tumbuh gulma, tinggi tanaman, diameter batang, jumlah daun, kehijauan daun, dan biomassa tanaman kelapa sawit.

\section{Hasil dan Pembahasan}

Analisis kandungan alelokimia Lantana camara. Hasil analisis uji kuantitatif kandungan senyawa menunjukkan bahwa bioherbisida Lantana camara mengandung senyawa Saponin $(2,07 \%)$, Flavonoid (1,83\%), dan Tanin (3,28\%). Senyawa Saponin dan Tanin pada bioherbisida Lantana camara menghambat pertumbuhan gulma dengan mengganggu proses pembentukan protein. Saponin menghambat enzim yang menyebabkan penurunan penggunaan protein, sedangkan Tanin menghambat pembentukan protein (Tavares et al., 2015; Deaville et al., 2010). Senyawa Tanin bekerja dengan menghambat hormon auksin pada gulma (Faqihhudin, 2014). Pembentukan protein yang terhanbat dan ketersediaan hormon auksin yang berkurang membuat gulma tidak mampu tumbuh, jumlah gulma yang berkurang tersebut akan menghilangkan kompetisi sarana tumbuh dengan tanaman utama yaitu kelapa sawit.

Jumlah gulma di pembibitan. Pemberian bioherbisida Lantana camara berpengaruh nyata pada jumlah gulma setelah aplikasi yang kedua, sedangkan pada aplikasi yang pertama tidak menunjukkan pengaruh yang nyata. Jumlah gulma terendah terdapat pada perlakuan ekstrak $1 \%$ dan tidak berbeda nyata dengan ekstrak 2\% dan 3\%, namun berbeda nyata dengan perlakuan kontrol (Tabel 1).

Jumlah gulma pada berbagai perlakuan ekstrak berbeda nyata dengan kontrol. Hal ini menunjukkan bahwa bioherbisida Lantana camara mampu menghambat pertumbuhan awal gulma di dalam tanah. Adanya senyawa alelokimia Lantana camara berpengaruh terhadap penekanan jumlah gulma pada pembibitan. Bioherbisida berpotensi sebagai metode alternatif pengendalian gulma yang lebih ramah lingkungan karena mengandung senyawa-senyawa kimia yang lebih alami (Bailey, 2014).

Tabel 1. Pengaruh pemberian berbagai konsentrasi ekstrak bioherbisida Lantana camara terhadap jumlah gulma

\begin{tabular}{ccc}
\hline \multirow{2}{*}{ Perlakuan } & \multicolumn{2}{c}{ Jumlah Gulma } \\
\cline { 2 - 3 } & $\begin{array}{c}\text { Setelah } \\
\text { Aplikasi 1 }\end{array}$ & $\begin{array}{c}\text { Setelah } \\
\text { Aplikasi 2 }\end{array}$ \\
\hline Kontrol & 3,45 & $5,00 \mathrm{a}$ \\
*Ekstrak LC 1\% & 2,34 & $1,88 \mathrm{~b}$ \\
Ekstrak LC 2\% & 2,23 & $3,56 \mathrm{~b}$ \\
Ekstrak LC 3\% & 4,66 & $2,01 \mathrm{~b}$ \\
\hline
\end{tabular}

Keterangan: Angka-angka yang diikuti oleh huruf yang berbeda pada kolom yang sama menunjukkan berbeda nyata menurut uji DMRT pada taraf nyata $5 \%$. Ekstrak LC = ekstrak Lantana camara

Tinggi bibit kelapa sawit (cm). Aplikasi bioherbisida Lantana camara berpengaruh nyata terhadap tinggi bibit kelapa sawit umur 3 Bulan Setelah Tanam (BST). Tinggi bibit kelapa sawit tertinggi pada 3 BST terdapat pada perlakuan kontrol dan tidak berbeda nyata pada perlakuan ekstrak 2\%, namun berbeda nyata dengan perlakuan ekstrak 1\% dan 3\% (Tabel 2).

Tabel 2. Pengaruh pemberian berbagai konsentrasi ekstrak bioherbisida Lantana camara terhadap tinggi tanaman

\begin{tabular}{cccc}
\hline \multirow{2}{*}{ Perlakuan } & \multicolumn{3}{c}{ Umur (BST) } \\
\cline { 2 - 4 } & \multicolumn{3}{c}{2} \\
\cline { 2 - 4 } & --- Tinggi Tanaman (cm)---- \\
\hline Kontrol & 4,92 & 14,77 & $22,43 \mathrm{a}$ \\
*Ekstrak LC 1\% & 5,69 & 12,39 & $16,92 \mathrm{c}$ \\
Ekstrak LC 2\% & 6,83 & 14,16 & $19,96 \mathrm{ab}$ \\
Ekstrak LC 3\% & 6,24 & 11,52 & $17,87 \mathrm{bc}$ \\
\hline
\end{tabular}

Keterangan: Angka-angka yang diikuti oleh huruf yang berbeda pada kolom yang sama menunjukkan berbeda nyata menurut uji DMRT pada taraf nyata 5\%. Ekstrak LC = ekstrak Lantana camara.

Perlakuan tanpa ekstrak menghasilkan bibit kelapa sawit tertinggi dibandingkan tiga perlakuan tanpa ekstrak lainnya, hal ini menunjukkan bahwa ekstrak mempengaruhi 
pertumbuhan bibit karena senyawa yang dikandungnya. Pertumbuhan bibit pada perlakuan ekstrak kurang optimal dibandingkan tanpa ekstrak. Namun, rata-rata pertumbuhan tinggi bibit pada ketiga perlakuan ekstrak masih tergolong normal $(18,25 \mathrm{~cm})$. Sari dan Toto (2018) melaporkan bahwa rata-rata pertumbuhan bibit kelapa sawit Sue Supreme dengan media tanam sub soil dan kotoran sapi adalah $17,60 \mathrm{~cm}$ sampai $18,55 \mathrm{~cm}$.

Tinggi bibit kelapa sawit pada perlakuan ekstrak yang kurang optimal tersebut disebabkan adanya mikroorganisme di dalam media tanam yang membuat senyawa alelokimia bersifat toksik. Inderjid (2005) menyatakan bahwa senyawa yang dilepaskan tumbuhan mungkin tidak bersifat toksik, namun produk degradasi senyawa alelokimia oleh mikroorganisme akan menghasilkan senyawa toksik.

Jumlah daun bibit kelapa sawit. Aplikasi bioherbisida Lantana camara tidak berpengaruh nyata terhadap jumlah daun bibit kelapa sawit umur 1 sampai 3 BST (Tabel 3). Hal ini disebabkan media tanam yang digunakan pada semua perlakuan mengandung unsur hara nitrogen yang cukup untuk kebutuhan pertumbuhan vegetatif bibit. Media tanam top soil mengandung 0,35\% $\mathrm{N}$ dan kompos kotoran sapi $0,59 \%$ N. Berdasarkan kriteria kecukupan unsur hara Balai Penelitian Tanah (2009), kedua kadar unsur hara tersebut masing-masing tergolong sedang dan tinggi.

Tabel 3. Pengaruh pemberian berbagai konsentrasi ekstrak bioherbisida Lantana camara terhadap jumlah daun

\begin{tabular}{cccc}
\hline \multirow{2}{*}{ Perlakuan } & \multicolumn{3}{c}{ Umur (BST) } \\
\cline { 2 - 4 } & 1 & 2 & 3 \\
\cline { 2 - 4 } & ---- & Jumlah daun (helai)---- \\
\hline Kontrol & 1,78 & 2,78 & 3,78 \\
*Ekstrak LC 1\% & 1,89 & 2,44 & 3,44 \\
Ekstrak LC 2\% & 1,67 & 2,78 & 3,78 \\
Ekstrak LC 3\% & 1,67 & 2,22 & 3,44
\end{tabular}

Keterangan: Angka-angka yang diikuti oleh huruf yang berbeda pada kolom yang sama menunjukkan berbeda nyata menurut uji DMRT pada taraf nyata $5 \%$. Ekstrak LC = ekstrak Lantana camara

Unsur hara Nitrogen berperan penting dalam meningkatkan pertumbuhan vegetatif tanaman, khususnya pada pembentukan daun (Hanafiah, 2005). Tanaman yang memiliki jumlah daun optimal akan tumbuh subur karena daun merupakan tempat proses fotosintesis yang menghasilkan karbohidrat dan energi tumbuh bagi tanaman (Pamungkas dan Supijatno, 2017).

Diameter Batang Bibit Kelapa Sawit. Pemberian bioherbisida Lantana camara berpengaruh nyata pada diameter batang bibit kelapa sawit umur 1 BST. Diameter batang tertinggi terdapat pada perlakuan kontrol, dan tidak berbeda nyata pada perlakuan ekstrak $1 \%$ dan $2 \%$. Pertumbuhan diameter batang pada 2 dan 3 BST tidak menunjukkan pengaruh yang nyata pada 2 dan 3 BST (Tabel 4).

Tabel 4. Pengaruh pemberian berbagai konsentrasi ekstrak bioherbisida Lantana camara terhadap diameter batang.

\begin{tabular}{clcc}
\hline \multirow{2}{*}{ Perlakuan } & \multicolumn{3}{c}{ Umur (BST) } \\
\cline { 2 - 4 } & \multicolumn{3}{c}{---- diameter batang (cm)---- } \\
\cline { 2 - 4 } & $4,44 \mathrm{a}$ & 4,33 & 5,72 \\
Kontrol & $4,43 \mathrm{a}$ & 3,46 & 4,60 \\
*Ekstrak LC 1\% & 4,13 & 5,63 \\
Ekstrak LC 2\% & $4,39 \mathrm{a}$ & 4,13 & 5,04 \\
Ekstrak LC 3\% & $4,36 \mathrm{~b}$ & 3,62 & \\
\hline
\end{tabular}

Keterangan: Angka-angka yang diikuti oleh huruf yang berbeda pada kolom yang sama menunjukkan berbeda nyata menurut uji DMRT 5\%. Ekstrak LC = ekstrak Lantana camara

Diameter batang bibit kelapa sawit tertinggi pada 1 BST terdapat pada perlakuan kontrol dan tidak berbeda nyata pada perlakuan ekstrak $1 \%$ dan $2 \%$. Hal ini menunjukkan bahwa senyawa alelokimia pada ekstrak juga mengurangi pertumbuhan diameter bibit kelapa sawit. Diameter batang dapat dijadikan indikator pertumbuhan, karena batang yang lebar dan kokoh diperlukan untuk menopang buah di masa pertumbuhan tanaman kelapa sawit selanjutnya.

Pertumbuhan diameter batang pada umur 2 dan 3 BST tidak menunjukkan pengaruh nyata, hal ini disebabkan keempat perlakuan mendapatkan media tanam yang sama dan mengandung unsur hara kalium yang sangat tinggi (Sub-soil 0,02\% dan kompos kotoran sapi $1,95 \%)$. Kalium yang meningkat pada media tanam berperan dalam pertumbuhan jaringan meristematik terutama batang. Hal ini dapat menguatkan tanaman sehingga tidak mudah rebah (Ariyanti et al., 2018). 
Kehijauan Daun Bibit Kelapa Sawit. Tingkat kehijauan daun menunjukkan bahwa tanaman mengandung unsur hara Nitrogen yang cukup dan kondisi tanaman yang sehat. Nilai kehijauan daun yang tinggi menunjukkan kandungan klorofil dalam daun tinggi dan dapat meningkatkan pertumbuhan tanaman (Pamungkas dan Supijatno, 2017). Nilai kehijauan daun menunjukkan hasil yang tidak berbeda nyata, hal ini berarti keempat perlakuan mendapatkan unsur hara nitrogen yang optimal sehingga mendukung nilai kehijauan daun yang tinggi.

Tabel 5. Pengaruh pemberian berbagai konsentrasi ekstrak bioherbisida Lantana camara terhadap kehijauan daun

\begin{tabular}{cc}
\hline Perlakuan & Kehijauan daun \\
\hline Kontrol & 59,58 \\
${ }^{*}$ Ekstrak LC 1\% & 48,15 \\
Ekstrak LC 2\% & 49,10 \\
Ekstrak LC 1\% & 55,38 \\
\hline
\end{tabular}

Keterangan: Angka-angka yang diikuti oleh huruf yang berbeda pada kolom yang sama menunjukkan berbeda nyata menurut uji DMRT pada taraf nyata $5 \%$. Ekstrak LC = ekstrak Lantana camara

Biomassa Bibit Kelapa Sawit (gram). Aplikasi bioherbisida Lantana camara tidak berpengaruh nyata terhadap biomassa bibit kelapa sawit (Tabel 6). Biomassa tanaman terbagi menjadi bobot basah dan kering, serta diukur pada akar dan tajuk bibit.

Tabel 6. Pengaruh pemberian berbagai konsentrasi ekstrak bioherbisida Lantana camara terhadap biomassa

\begin{tabular}{ccccc}
\hline \multirow{2}{*}{ Perlakuan } & \multicolumn{2}{c}{ Bobot Basah } & \multicolumn{2}{c}{ Bobot Kering } \\
\cline { 2 - 5 } & Akar & Tajuk & Akar & Tajuk \\
\cline { 2 - 5 } & \multicolumn{4}{c}{----- gram ------ } \\
\hline Kontrol & 1,32 & 3,32 & 0,31 & 0,72 \\
*Ekstrak LC 1\% & 0,87 & 2,95 & 0,21 & 0,65 \\
Ekstrak LC 2\% & 0,80 & 2,69 & 0,18 & 0,55 \\
Ekstrak LC 1\% & 0,88 & 2,39 & 0,24 & 0,51 \\
\hline
\end{tabular}

Keterangan: Angka-angka yang diikuti oleh huruf yang berbeda pada kolom yang sama menunjukkan berbeda nyata menurut uji DMRT pada taraf nyata $5 \%$. Ekstrak LC $=$ ekstrak Lantana camara

Nilai biomassa tanaman sejalan dengan nilai morfologi bibit kelapa sawit, perlakuan yang menunjukkan nilai morfologi tertinggi juga menghasilkan biomassa tertinggi. Hal ini menunjukkan bahwa hasil akumulasi fotosintesis yang dihasilkan mampu terdistribusi dengan baik ke seluruh bagian tanaman. Zulyana (2011) menyatakan bahwa bobot basah dan bobot kering akan meningkat jika fotosintesis meningkat, sehingga biomassa akan terserap seiring dengan berjalannya proses fotosintesis.

Biomassa bibit kelapa sawit yang tidak berpengaruh nyata menunjukkan bahwa ekstrak yang mengandung senyawa alelokimia tidak menghambat reaksi-reaksi penting dalam pertumbuhan bibit. Bioherbisida secara nyata dapat menekan pertumbuhan gulma, dan tidak mengganggu pertumbuhan tanaman. Selain itu, secara tidak langsung bioherbisida juga dapat menambah bahan organik bagi media tanam. Hal ini tentunya akan menambah pasokan unsur hara bagi tanaman utama. Krisno (2016) menyatakan bahwa pasokan bahan organik yang memadai akan menguntungkan lahan atau media tanam. Bahan organik juga memainkan peran cukup besar dalam mempengaruhi perilaku atau kegiatan di dalam tanah seperti biodegradasi, pencucian, dan penguapan.

\section{Kesimpulan}

1. Bioherbisida Lantana camara mengandung senyawa alelokimia yaitu Alkaloid, Saponin $(2.07 \%)$, Tanin $(3.28 \%)$, Fenolik, Flavonoid (1.83\%), Triterpenoid, Steroid, Glikosida.

2. Bioherbisida Lantana camara berpengaruh nyata terhadap penurunan daya tumbuh gulma, namun menekan tinggi bibit (3 BST), dan diameter batang (1 BST), namun bibit masih tergolong normal dan sehat.

3. Bioherbisida Lantana camara dengan konsentrasi $1 \%$ menunjukkan hasil terbaik dalam menekan laju pertumbuhan gulma, dan secara umum tidak mengganggu pertumbuhan bibit kelapa sawit. Namun, penelitian lebih lanjut tetap perlu dilakukan untuk mengetahui dampak jangka panjang terhadap pertumbuhan bibit dan biaya yang diperlukan.

\section{Daftar Pustaka}

Antika, R.S., S. Nanik, dan Sugiatno. 2014. Uji fitotoksisitas herbisida Aminosiklopiraklor pada bibit kelapa sawit (Elaeis guineensis Jacq.). Jurnal Agrotek Tropika. 2(3): 424-430. 
Ariyanti, M., R.D. Intan, M. Yudithia, dan A.C. Yudha. 2018. Pertumbuhan bibit kelapa sawit (Elaeis guineensis Jacq.) dengan komposisi media tanam dan interval penyiraman yang berbeda. Jurnal Penelitian Kelapa Sawit. 26(11): 11-22.

Asrani, D. 2010. Pemanfaatan gulma babandotan dan tembelekan dalam pengendalian Sitophillus SPP. pada benih jagung. Jurnal Agrisains 1(1): 58-59.

Bailey, K.L. 2014. The Bioherbicide Approach to Weed Control Using Plant Pathogens. The Integrated Pest Management. London (USA): Elsevier Academic Press.

Balai Penelitian Tanah. 2009. Analisis Kimia Tanah, Tanaman, Air dan Pupuk (Petunjuk Teknis Edisi 2). Jakarta (ID) : Balai Penelitian Tanah, Badan Besar Litbang Sumber Daya Lahan Pertanian, Departemen Pertanian.

Deaville, E. R., D. I. Givens, and I. MuelerHarvey. 2010. Chesnut and Mimosa tannin silages: Effect in sheep differ for apparent digestibilty, nitrogen utilitation and losses. Animal Feed Science and Technology Journal. 157: 129-138.

Faqihhudin. 2014. Penggunaan Herbisida IPAGlifosat terhadap Pertumbuhan, Hasil dan Residu pada Jagung. Jurnal Ilmu Pertanian. 17(1): 122-125.

Hanafiah, K.A. 2005. Dasar-Dasar Ilmu Tanah. Raja Grafindo Persada. Jakarta.

Inderjid. 2005. Soil microorganisms: An Important Determinant of Allelopathic Activity. Plant Soil Journal. 273(2): 227-236.

Krisno, M.A.B., 2016. Pembuatan herbisida organic di kelompok tani sumber URIP-1 Desa Wonorejo Kecamatan Poncokusumo Kabupaten Malang. J. Dedikasi. 13: 75-82.
Mirnawati., P. Rhamadhani, S. Nengah. 2017. Uji efektivitas ekstrak daun tahi ayam (Lantana camara) sebagai bioherbisida alami terhadap perkecambahan biji akasia berduri (Acacia nolitica (L.). [Skripsi]. Sulawesi (ID): Universitas Tadulako.

Pamungkas, M. A. dan Supijatno. 2017. Pengaruh pemupukan Nitrogen terhadap tinggi dan percabangan tanaman teh (Camellia sinensis (L.) O. Kuntze) untuk pembentukan bidang petik. Buletin Agronomi. 5(2): 234-241.

Rambe, T. D., P. Lasiman, Sudharto, dan J. P. Caliman. 2010. Pengelolaan Gulma pada Perkebunan Kelapa Sawit. PT Smart TBK. Jakarta.

Sari, V. I. 2018. Pemanfaatan gulma saliara (Lantana camara L.) sebagai bioherbisida pra tumbuh dan pengolahan tanah untuk pengendalian gulma di areal perkebunan kelapa sawit. Jurnal Agrosintesa. 1(1): 10-17.

Sari, V. I. dan S. Toto. 2018. Tanggap pertumbuhan morfologi dan fisiologi bibit kelapa sawit (Elaeis guineensis Jacq.) di pembibitan awal (pre nursery) dengan metode penanaman vertikultur. Prosiding Seminar Nasional Fakultas Pertanian Universitas Jambi Tahun 2018. Hal 191-201.

Tavares, R. L., A. S. Silva, A. R. N. Campos, A. R. P. Schuler, and J. A. de Sousa. 2015. Nutritional composition, phytochemicals and microbiological quality of the legume, Mucuna pruriens. African. Journal of Biotechnology. 14(8): 676- 682.

Zulyana, U. 2011. Respon ketimun (Cucumis sativus) terhadap pemberian kombinasi Dosis Dan Macam Bentuk Pupuk Kotoran Sapi Di Getasan. [Skripsi]. Surakarta (ID): Universitas Sebelas Maret. 